\title{
Dynamics and dilemmas in social psychology: Social relations, identities and cognition
}

\begin{abstract}
This paper aims to provide a systematised overview of the paradigmatic orientations in social psychology in Portugal by identifying the most cited publications. Results show that the eight most cited thematic are: (1) deviance and reactions to deviance, (2) methodology, (3) prejudice and discrimination, (4) gender studies, (5) risk, environment and safety, (6) information processing, social judgment, familiarity and mood, (7) social representations and (8) social justice and belief in a just world. These eight most salient thematics can be sorted into three current paradigmatic orientations in contemporary social psychology: (a) social cognition; (b) the study of collective beliefs, ideologies and social representations; and (c) the study of identity and its impact on intra- and intergroup processes. The paper finishes with a reflection on the future developments of the discipline and the dilemmas that social psychology in Portugal could face.
\end{abstract}

This paper aims to provide a general depiction of the state of social psychology in Portugal drawing on the work published in recent years within this discipline. ${ }^{1}$ To comply with the proposed goal, we will consider the published work with

\section{KEYWORDS}

identity social relations cognition social representation collective beliefs

1. We thankfully acknowledge the invitation from Paula Castro and Luisa Oliveira to develop this work and we extend our appreciation to João Ferreira de Almeida for the initiative of creating the Portuguese Journal of Social Science ten years ago. 
most impact on the scientific community, categorising it by research domains and considering the reference theories and models.

For a better understanding and contextualisation of our approach, it is important to bear in mind that social psychology in Portugal is a recent social discipline. Also important is the fact that from its beginning social psychology in Portugal has been built upon a basis of an international scope, namely being strongly influenced by the European social psychology. Indeed Portuguese social psychologists consider as the founding act of the modern social psychology in Portugal the symposium that took place in 1980 at the Calouste Gulbenkian Foundation entitled Social change and social psychology (Lima, Castro and Garrido 2003; Knoke 1982). The symposium included the presence of three of the main founders of modern European social psychology: Henri Tajfel, author of one of the most influential theories about identity, social identity and social change (Tajfel and Turner 1979); Willem Doise, whose theory on categorical differentiation had an enormous impact on the socio-cognitive analysis of relations and conflicts between social groups and who developed a specific theory about social representations (Doise 1976; Doise, Clémence and Lorenzi-Cioldi 1993); and Jacques-Philippe Leyens whose work on the domain of impression formation (Leyens, Yzerbyt and Schadron 1992) and, later, on the processes of infrahumanization (Leyens et al. 2000) have become reference pieces.

Later, the research networks, collaborations, and influences on Portuguese research on social psychology expanded to the United States. Another aspect of the history of social psychology in Portugal (which is also something not completely uncharacteristic considering the amount of examples throughout the world, namely in the Netherlands), is that this discipline developed, to a large extent, together with organisational psychology. However, the focus of this paper is on social psychology per se.

\section{DRAWING A PICTURE OF SOCIAL PSYCHOLOGY IN PORTUGAL}

The situation of social psychology has been reflected upon before either within the more general analysis of the fundamental topics most studied within general psychology (Alferes et al. 2009) or regarding social psychology specifically (Vala 1992). However, the paper of Alferes et al. not only focused solely on the papers published in Portuguese journals but also does a comprehensive analysis that includes all papers regardless of their impact in the field; and the second example was a very extensive diagnostics of the research in psychology and specifically in social psychology in Portugal but was done 20 years ago.

In the present paper, to depict the current situation of social psychology as a scientific discipline in Portugal, we focus on the topics that received most attention in the recent years. We use Harzing Publish or Perish (Harzing 2007) as a tool for such task. Harzing Publish or Perish is a citation analysis software program that allows quantifying the pervasiveness of scientific topics and the magnitude of citation of different authors. Using this tool, we will identify the scientific topics of social psychology developed in Portugal that garnered the most attention within the scientific community of social psychology worldwide, including the Anglo-Saxon universe but going beyond it. Consequently, this database allows a more comprehensive and wide measurement of the impact of such works over and above the specific impact in journals with impact factors, like the ISI tool. Comparatively to a database such as Scopus, which also covers citations in books (and not only in journals), Harzing has the advantage of being more 
comprehensive in the kind of documental outputs it includes, even though it is affected with more flaws in the identification of documents. Our hypothesis is that this kind of error is not significant and affects all authors equally.

Considering that an exhaustive and non-discretionary identification of the topics cited would prove unfeasible and uninformative, we have established two criteria to structure our analysis. We chose to consider only papers that have a number of citations above 15 and only when referring to a scientific topic that, in total (considering other papers) garners more than 50 citations.

\section{LIST OF MOST CITED TOPICS IN SOCIAL PSYCHOLOGY IN PORTUGAL}

Our analysis identified 59 papers that were cited a total of 3,608 times covering eight main topics. This means each paper was cited a mean of 61 times. Table 1 contains a list of the most cited topics organised by a categorisation that emerged from the data. Therefore it comprises different levels of abstraction, but does identify the clusters of work developed within this discipline. The order of the presented topics follows from the most to the least cited topic.

By far, the most cited scientific topic developed in Portuguese social psychology refers to a theoretical approach to social deviance and the reactions to deviants, where a specific phenomenon has been identified - the 'black sheep effect' (e.g. Marques, Yzerbyt and Leyens 1988; Marques, Abrams and Serôdio 2001). This work will be more thoroughly described later.

\begin{tabular}{|c|c|c|c|}
\hline Topic & $\begin{array}{l}\text { Total } \\
\text { Citations } \\
(3608)\end{array}$ & $\begin{array}{l}\text { Total } \\
\text { Papers } \\
\text { (59) }\end{array}$ & Most Cited Authors \\
\hline $\begin{array}{l}\text { Intra-group phenomena; } \\
\text { deviance and reactions to } \\
\text { deviance }\end{array}$ & 929 & 6 & José Marques \\
\hline Methodology & 695 & 3 & $\begin{array}{l}\text { Jorge Vala, Valentim } \\
\text { Alferes, Félix Neto }\end{array}$ \\
\hline $\begin{array}{l}\text { Intergroup relations; } \\
\text { prejudice; discrimination }\end{array}$ & 459 & 12 & $\begin{array}{l}\text { Jorge Vala, Maria } \\
\text { Benedicta Monteiro, } \\
\text { Sven Waldzus, Rosa } \\
\text { Cabecinhas }\end{array}$ \\
\hline Gender studies & 388 & 7 & $\begin{array}{l}\text { Ligia Amâncio, Manuela } \\
\text { Barreto }\end{array}$ \\
\hline $\begin{array}{l}\text { Risk, environment and } \\
\text { safety }\end{array}$ & 365 & 9 & $\begin{array}{l}\text { Luisa Lima, Paula Castro, } \\
\text { Sílvia Silva }\end{array}$ \\
\hline $\begin{array}{l}\text { Information processing, } \\
\text { social judgment, familiar- } \\
\text { ity and mood }\end{array}$ & 296 & 9 & $\begin{array}{l}\text { Leonel Garcia-Marques, } \\
\text { Mário Ferreira, Teresa } \\
\text { Garcia-Marques }\end{array}$ \\
\hline Social representations & 261 & 6 & Jorge Vala, Paula Castro \\
\hline $\begin{array}{l}\text { Social justice; belief in a } \\
\text { just world }\end{array}$ & 163 & 5 & Isabel Correia, Jorge Vala \\
\hline
\end{tabular}

Table 1: Most cited topics in social psychology in Portugal (Harzing Publish or Perish, December 2011). 
The second most cited topic refers to methodological issues that reflect a very important concern for the theoretical and analytical examination of the research procedures within this discipline at the level of the qualitative methods, as well as quantitative and experimental ones. The third and fourth most cited topics refer to intergroup relations, either focusing on prejudice, racism (e.g. Cabecinhas 2008; Monteiro, França and Rodrigues 2009; Vala, Brito and Lopes 1999; Waldzus, Mummendey and Wenzel 2005) or gender issues (e.g. Amâncio 1994). The topic of intergroup relations, conflict and aggression is probably the most prolific subject not only in Portugal but also in other European and non-European countries. It shaped social psychology since the beginning of the 20th century and particularly after the Second World War.

At the bottom half of the table we find three issues that refer to different types of collective beliefs and their effects on attitudes and behaviour, and include research on risk and environment (e.g. Castro and Lima 2001; Lima 2004), safety (Silva, Baptista and Lima 2004) and social justice (e.g. Correia, Vala and Aguiar 2007).

Finally, we should emphasise the topics that represent the social cognition paradigm in social psychology (e.g. Ferreira et al. 2006; Garcia-Marques, Hamilton and Maddox 2002; Garcia-Marques and Mackie 1999; 2001). In fact, this paradigm has been among the most cited topics in social psychology in other European countries and the United States since the 1990s, but has only in recent years become the target of an increasing attention in Portugal.

\section{Social cognition, ideologies, and identity and relations}

The eight topics may be grouped under three major theoretical blocks that reflect different epistemological orientations in social psychology. Table 2 presents these three blocks with the indication of the different thematic included in each one.

The first block includes theories, models and topics based on the cognitive constraints that determine representations about people and groups, constituting the social cognition tradition mentioned above (Bruner and Taguiuri 1954; Fiske and Taylor 2008 [1991]; Kunda 1999).

The second block includes topics based on the social constraints that determine collective representations of social phenomena (Bruner 1957; Moscovici 1961), following the hypothesis of Bruner according to which it is the society that shapes the mind.

\begin{tabular}{|c|c|}
\hline Block & Thematics included \\
\hline Social cognition & $\begin{array}{l}\text { Information processing; } \\
\text { stereotypes; impression formation; } \\
\text { familiarity and mood }\end{array}$ \\
\hline $\begin{array}{l}\text { Collective beliefs, ideologies and } \\
\text { social representations }\end{array}$ & $\begin{array}{l}\text { Social justice; social representations; } \\
\text { risk, environment and safety }\end{array}$ \\
\hline $\begin{array}{l}\text { Identity and intra- } \\
\text { and intergroup relations }\end{array}$ & $\begin{array}{l}\text { Intra- and inter-group relations; } \\
\text { deviance; prejudice and } \\
\text { discrimination }\end{array}$ \\
\hline
\end{tabular}

Table 2: Theoretical blocks in social psychology in Portugal. 
The third and final block includes work building on motivational and identity processes and on the nature of intra- and inter-group relations to explain attitudes and collective behaviour. Therefore, the first two blocks represent a higher influence of cognitive factors while in the third motivational factors play a larger role, with a specific focus on the construction and upholding of individual and group identity.

In order to get a better understanding of what is included in each of these blocks, we will present an example of a research topic for each of them.

One of the most cited topics within the social cognition block refers to the twofold retrieval by associative pathways (TRAP) model (Garcia-Marques and Hamiltonl, 1996; 2012; Garcia-Marques, Hamilton and Maddox 2002). The TRAP model was conceived to explain the divergent effects of information that is congruent or incongruent with the stereotypes. In fact, it had been previously shown that on the one hand in social life we have a tendency to sometimes remember the information that is congruent with our previous beliefs better, in an attempt to confirm these beliefs. On the other hand, incongruent information is extensively processed and is sometimes more easily evoked. The TRAP model allowed conciliating these two apparently contradictory effects suggesting the two effects reflect two distinct strategies of retrieval and information processing. One strategy is called 'exhaustive' and represents an effortful search process that navigates sequentially through associative memory. The other strategy is more automatic and is designated as 'heuristic' and corresponds to a fast and low resource-demanding process.

This is a model with both a direct and indirect social impact. The model addresses the processes underlying the impressions we form about others and social judgments in general, even though it does not focus directly on the consequences of these processes and judgments. However, the importance of the processes elucidated by the model is immense. For instance, when forming impressions of others or when making decisions about social groups, the two strategies identified in the model lead to different social consequences: on the one hand, the quick and automatic processing of the heuristic pathway will lead to a confirmation of stereotypes, on the other hand, the most effortful processing of an exhaustive pathway may produce higher and unbalanced attention towards incongruent information.

The theoretical block that refers to collective beliefs, ideologies and social representations is a comprehensive one that gathers very diverse pieces of research, including work on representations and beliefs about risk, environment, safety or justice and its impact on different social attitudes and behaviours. Most of this work builds on the theoretical paradigm of social representations (Moscovici 1961; 1984; Castro 2006).

One example of research within this block involves beliefs about justice and its relation with the way people feel towards victims of suffering (Correia, Vala and Aguiar 2007). Specifically, this research is related with the belief in a just world (Lerner 1980) according to each everyone gets what they deserve and deserve what they get. This belief would have its roots in the primal experiences of association between positive behaviours and positive reinforcements and would be fundamental to deal with the future and justify personal investment. In this vein, this belief is also essential to understand the way we relate to victims, especially with victims perceived as innocent. If a person suffers it might be because they deserve it. But if the victim of suffering is innocent, such suffering threatens the belief in a just world. Therefore people will develop strategies to reassure such belief. One logical strategy would be 
to re-establish justice by helping the victim through emotional or instrumental support, for example, by acting upon the circumstances that generated the suffering and injustice. Another strategy, however, may involve a secondary victimisation, that is, to attribute guilt and responsibility to the victim for the circumstances they are in (see Correia and Vala 2003). This belief in a just world has been presented a good example of a social representation (Doise 1982) and feeds the meritocratic-liberal ideology.

Correia, Vala and Aguiar (2007) innovatively articulated these aspects with the intergroup perspective and analysed whether being confronted with an innocent victim from our own group ('ingroup') or those from a different group ('outgroup') had a different impact on the belief in a just world. Their results showed that when people were confronted with victims from their 'ingroup' their belief in a just world was significantly affected, and, as expected, an innocent victim was more threatening than a non-innocent one. However, and more interestingly, being confronted with victims that belong to an 'outgroup' does not threaten our belief in a just world.

The final block represents what is probably the most prolific research topic in social psychology: intra- and inter-group phenomena. As we mentioned above, the topic of racism, prejudice, discrimination and inter-group conflict in general constitutes one of the most developed topics in social psychology in Portugal. Nevertheless, the topic developed that is most cited in the international context refers to an approach to deviance and the punishment of deviants. Within this approach, a specific phenomenon has received a very significant attention - the aforementioned 'black sheep' effect (Marques, Yzerbyt and Leyens 1988; Marques, Abrams and Serôdio 2001; Marques and Páez 1994; Marques et al. 1998).

The black sheep effect reports to a specific differential treatment of 'ingroup' and 'outgroup' members where normative 'ingroup' members are judged more positively than similar 'outgroup' members, while deviant 'ingroup' members are judged more negatively than similar 'outgroup' members. The rationale for such phenomenon is that the punishment of an 'ingroup' deviant allows the protection of the positive social identity of the 'ingroup' and the reinforcement of the norms common to both 'ingroup' and 'outgroup': by saying the deviant is not positively regarded we reinforce the norm that is being transgressed with that deviance. This research directly follows some of the most important theories on interpersonal and intergroup behaviour within social psychology, namely the traditional research on group uniformity (Cartwright and Zander 1968; Festinger 1950) and the more recent research on social identity (Tajfel and Turner 1979; Turner et al. 1987; Hogg and Abrams 1988) and 'outgroup' homogeneity (Park, Judd and Ryan 1991). It should be noted, however, that the work developed by Marques et al. emerges from a general concern with the societal issue of deviance and not so much with the intra-group phenomena in itself. One could say that the black sheep effect is an intra-group manifestation of a more societal phenomenon of response to deviance in societies. This phenomenon has been dealt with within the more general theoretical model - subjective group dynamics model - that refers to the cognitive, evaluative and emotional processes that allow individuals to maximise and maintain a positive social identity (Marques, Abrams and Serôdio 2001; Pinto et al. 2010). Despite its roots in social psychology, this model, and particularly the black sheep effect, also builds to some extent on Durkheim's own work on deviance (Durkheim 2010 [1897]) and the idea of reinforcement of moral borders and solidarity between individuals through punishment of deviants. 


\section{FUTURE DEVELOPMENTS}

After this description of the most cited topics in social psychology in Portugal, we would like to provide a short note on the future developments of the discipline in the Portuguese context. Contrary to the previous section where our statements are based on observational arguments, here we offer some insights on what we intuit to be two major paths in the development of this discipline in the near future. Firstly, we believe that we will witness a general expansion of perspectives that propose the articulation of different levels of analysis: from the social neurosciences to the study of ideologies, social representations and social structures.

Secondly, we believe two main social problems will structure the research in this domain (and in the other social sciences): health and social well-being, and social cohesion. The first problem derives from the natural life-extension we observe nowadays, the demographic problems, and the increasingly sharp conflict between the aspirations regarding quality of life and the lack of responses from social policies (see Coudin and Lima 2011; Calheiros, Garrido and Santos 2011). The second problem comes from the emerging conflicts of generations, the social inequalities (that tend to increase) and the new mechanisms of social repression that will characterise the democratic systems, increasing the dissociation between citizens and the political and financial power.

It could be expected that in this empirical context, two major concerns will structure the research in this field: one related to the social context and one that is linked with issues of social legitimation concerning the decision making processes about people, groups and social issues. Thus, on the one hand, research will start to pay more and more attention to the physical context and situational cues when looking for factors determining attitudes and behaviours (e.g. Palma, Garrido and Semin 2011; Garcia-Marques et al. 2012). On the other hand, social psychology (of intergroup conflicts in particular) will start to focus less on the roots and expressions of negative behaviour, namely intergroup bias, and focus more on the mechanisms that allow for its perpetuation in modern democratic societies (e.g. Pereira, Vala and Costa-Lopes 2010) and specifically on factors that legitimate the decisions about people and social groups in situations of scarce resources.

\section{DILEMMAS OF SOCIAL PSYCHOLOGY}

To look at the future of social psychology in Portugal means not only to identify the research thematic that are in expansion but also identify theoretical dilemmas the discipline will face. These dilemmas, however, are not new in a discipline born out of the crossing of disciplinary fields: psychology and sociology. We acknowledge the existence of two main dilemmas: (1) focus on society (social relations) versus individuals (brain); (2) focus on the individual 'subject' versus focus on the triple relation: ego-alter-object.

Regarding the first dilemma, one should bear in mind that the evolution of neurosciences is highly significant and represents a challenge for the social sciences. We cannot ignore the fascination this field exerts by offering neuronal-level explanations for individual and social processes. However, we must say that most of the work developed under this perspective in social psychology still very much follows a descriptive approach focusing on identifying the individual areas in the brain responsible for the mental processes. Nonetheless, the interchanges between social sciences and neurosciences may be mutually profitable. In the specific case of social psychology, 
ever since the start of the decade of the brain (the 1990s), the importance of such a perspective has been praised, but only within the realm of a multilevel approach namely based on the principle of multiple determinism, as underlined by Caciopo and Bernston (1992). In the words of those authors who coined the expression 'social neurosciences': 'thus, the decade of the brain is more likely to be a gateway to a new millennium of the mind if we recognise that the brain is a single, pivotal component of an undeniably social species' and if we recognise that the nature of the brain, behaviour and society is, in Bevan's words, orderly in its complexity rather than lawful in its simplicity' (1992: 1027; see also Fiske 2000). Even if the dilemma of 'social relations versus brain' may be overcome within a multiple determinism approach, a second highly complex dilemma remains.

Social psychology has been recurrently identified with what Moscovici (1972) termed a differentialist perspective, that is, studying individual characteristics with social impact from a personality differences perspective, with examples such as the authoritarian personality (Adorno et al 1993 [1950]) or the open and closed mind (Rokeach 1960). Also according to Moscovici, a second perspective that smothers the scope of social psychology is one that confuses this discipline with a taxonomic view of stimuli: social stimuli in opposition to non-social stimuli. Such a perspective, named taxonomic, would oppose a 'social reality' to a 'physical reality'. How does one overcome two such reductionist and epistemologically problematic perspectives? An easy answer that is difficult to implement would be to attribute to social psychology the study of the relations subject-object, as mediated by the relations subject-subject-object. It is within this triadic relation (Moscovici 1984) that the interface between social relations, identity processes and cognitions may be addressed in an innovative way (Castro 2006; Vala and Castro forthcoming).

Such disciplinary endeavour would elicit interdisciplinary dialogues that may allow social psychology to integrate the macro-social level of analysis in the generalisation of its results and overcome the simple synchronic dimension by considering the historical dimension in the study of the relations between subject-subject-object. Moreover, by adopting such perspective, social psychology will be able to demonstrate not only how culture, social knowledge and behaviours are less stable than what is usually anticipated, but also identify the processes through which these transformations occur: e.g. categorisation and social identity (e.g. Turner and Reynolds 2001), social comparison (e.g. Guimond 2006), negotiation of meanings (e.g. Higgins and Pittman 2008).

\section{CONCLUSIONS}

The goal of this paper was to provide a 'survey' of the recent orientations of the social psychology developed in Portugal, by identifying the most cited publications according to the database from Harzing Publish or Perish. Results show that the three most cited substantive topics are deviance and reactions to deviance, the relationships between groups and the phenomena of prejudice and discrimination associated to those relationships. On the whole, the eight most salient thematics can be sorted into three current paradigmatic orientations in contemporary social psychology: (1) social cognition; (2) the study of collective beliefs, ideologies and social representations; and (3) the study of identity and its impact on intra- and intergroup processes.

In prospective terms, we consider that social psychology in Portugal - as in other countries - will develop through its several paradigmatic orientations and 
not through one in particular. Moreover, we believe this discipline will progress in its understanding of the individual and collective phenomena insofar as it adopts a perspective that articulates levels of analysis and meta-theoretical orientations (Caciopo and Bernston 1992).

Twenty years ago, one of the authors of this paper sought to identify and systematise the research in psychology in Portugal (Vala 1992). Concerning social psychology, the field was already mapped in a way similar to the way we find it today. What we have witnessed was a deepening of the thematic topics, the emergence of a few endogenous innovative theories and models and the increase of international publications. This development in extension and depth has had a higher impact on the international community than on the national academic community, where the number of researchers and professors in social psychology remains very low. The discipline needs to increase its visibility in Portugal and open room for a rejuvenation of this scientific community.

\section{REFERENCES}

Adorno, T. W., Frenkel-Brunswik, E., Levinson, D. J. and Sanford, R. N. (1993 [1950]), The authoritarian personality, New York, NY: W. W. Norton.

Alferes, V. R., Bidarra, M. G., Lopes, C. A. and Mónico, L. S. (2009), ‘Domínios deinvestigação, orientações metodológicas e autores nas revistas portuguesas de psicologia: Tendências de publicação nas últimas quatro décadas do século XX', Análise Psicológica 27 (1): 3-20.

Amâncio, L. (1994), Masculino e feminine: A construção social da diferença, 2nd edn, Oporto: Afrontamento.

Bruner, J. A. (1957), 'Going beyond the information given', in Bruner, J. S., Brunswik, W., Festinger, L., Heider, F., Muenzinger, K. F., Osgood, C. E. and Rapaport, D. (eds), Contemporary approaches to cognition, Cambridge, MA: Harvard University Press, pp. 41-69.

Bruner, J.S. and Tagiuri, R. (1954), 'The perception of people', in Lindzey, G. (ed.), Handbook of social psychology, vol. 2, Reading, MA: Addison-Wesley, pp. 634-54.

Cabecinhas, R. (2008), Preto e branco: A natruralização da discriminação racial, Lisbon: Bertrand.

Cacioppo, J. T. and Berntson, G. G. (1992), 'Social psychological contributions to the decade of the brain: Doctrine of multilevel analysis', American Psychologist 47: 1019-28.

Calheiros, M., Garrido, M. and Santos, S. (2011), Children at risk and in danger: Contexts, research and intervention, vol. I, Lisbon: Silabo.

Cartwright, D. and Zander, A. (1968), Group Dynamics, London: Tavistock.

Castro, P. (2006), 'Applying social psychology to the study of environmental concern and environmental worldviews: Some contributions from social representations approach', Journal of Community and Applied Social Psychology 16: 247-66.

Castro, P. and Lima, M. L. (2001), 'Old and new ideas about the environment and science: An exploratory study', Environment and Behavior 33: 400-23.

Correia, I. and Vala, J. (2003), 'When will a victim be secondarily victimized? The effect of observer's belief in a just world, victim's innocence and persistence of suffering', Social Justice Research 16: 379-400.

Correia, I., Vala, J., and Aguiar, P. (2007), 'Victim's innocence, social categorization and the threat to the belief in a just world', Journal of Experimental Social Psychology 43: 31-8. 
Coudin, G. and Lima, M. L. (2011), 'Being well as time goes by: Future time perspective and well-being', International Journal of Psychology and Psychological Therapy 11 (2): 219-32.

Doise, W. (1982), L'explication en psychologie sociale, Paris: Presses universitaires de France.

Doise, W. (1976), L'articulation psychologique et les relations entre groups, Brussels: De Boeck.

Doise, W., Clémence, A. and Lorenzi-Cioldi, F. (1993), The quantitative analysis of social representations, Hempel Hempstead: Harvester Wheatsheaf.

Durkheim, E. (2010 [1897]), Suicide: A study in sociology, New York, NY: The Free Press.

Ferreira, M. B., Garcia-Marques, L., Sherman, S. J. and Sherman, J. (2006), 'A dual-process approach to judgment under uncertainty', Journal of Personality and Social Psychology 91 (5): 797-813.

Festinger, L. (1950), 'Informal social communication', Psychological Review 57: $271-82$.

Fiske, S. T. (2000), 'Stereotyping, prejudice, and discrimination at the seam between the centuries: Evolution, culture, mind and brain', European Journal of Social Psychology 30: 299-322.

Fiske, S. T. and Taylor, S. E. (2008 [1991]), Social cognition: From brains to culture, New York, NY: McGraw-Hill.

Garcia-Marques, L. and Hamilton (1996), 'Resolving the apparent discrepancy between the incongruency and the expectancy-based illusory correlation effects: The TRAP model', Journal of Personality and Social Psychology, 71: 845-61.

Garcia-Marques, L. and Mackie, D. M. (1999), 'The impact of stereotypeincongruent information on perceived group variability and stereotype change', Journal of Personality and Social Psychology 77: 979-90.

Garcia-Marques, L. and Mackie, D. M. (2001), 'Not all stereotype-incongruent information is created equal: The impact of sample variability on stereotype change', Group Processes and Intergroup Relations 4: 5-20.

Garcia-Marques, L., Garrido, M. V., Hamilton, D. L. and Ferreira, M. (2012), 'Effects of correspondence between encoding and retrieval organization in social memory,' Journal of Experimental Social Psychology 48: 200-6.

Garcia-Marques, L., Hamilton, D. L, and Maddox, K. B. (2002), 'Exhaustive and heuristic retrieval processes in person cognition: Further tests of the TRAP model,' Journal of Personality and Social Psychology 82: 193-207.

Guimond, S. (ed.) (2006), Social comparison and social psychology: Understanding cognition, intergroup relations and culture, Cambridge: Cambridge University Press.Harzing, A.W. (2007), Publish or perish, available atwww.harzing. com/pop.htm [Accessed 23 March 2012].

Higgins, E. T. and Pittman, T. S. (2008), 'Motives of the human animal: Comprehending, managing, and sharing inner states, Annual Review of Psychology 59: 361-85.

Hogg. M. A. and Abrams, D. (1988), Social identifications: A social psychology of intergroup relations, New York, NY: Routledge, Chapman and Hall.

Kunda, Z. (1999), Social cognition: Making sense of people, Cambridge, MA: The MIT Press.

Lerner, M. J. (1980), The belief in a just world: A fundamental delusion, New York, NY: Plenum.

Leyens, J., Paladino, P., Rodriguez-Torres, R., Vaes, J., Demoulin, S., RodriguezPerez, A. and Gaunt, R. (2000), 'The emotional side of prejudice: The 
attribution of secondary emotions to ingroups and outgroups', Personality and Social Psychology Review 4 (2): 186-97.

Leyens, J., Yzerbyt, V. Y. and Schadron, G. (1992), 'The social judgeability approach to stereotypes', in Stroebe, W. and Hewstone, M. (eds), European Review of Social Psychology, vol. 3, Chichester: Wiley.

Lima, M. L. (2004), 'On the influence of risk perception on mental health: Living near an incinerator', Journal of Environmental Psychology 24 (1): 71-84.

Lima, M. L., Castro, P. and Garrido, M. V. (2003), 'Identidade e diversidade na psicologia social europeia-contributos para a história da disciplina em Portugal', in Lima, M. L., Castro P. and Garrido, M. V. (eds), Temas e debates em psicologia social, Lisbon: Horizonte, pp. 11-36.

Marques, J. M., Abrams, D. and Serôdio, R. G. (2001), 'Being better by being right: Subjective group dynamics and derogation of in-group deviants when generic norms are undermined', Journal of Personality and Social Psychology 81: 436-47.

Marques, J. M., Abrams, D., Páez, D. and Taboada, C. M. (1998), 'The role of categorization and inroup norms in judgments of groups and their members', Journal of Personality and Social Psychology 75: 976-88.

Marques, J. M. and Páez, D. (1994), 'The black sheep effect: Social categorisation, rejection of ingroup deviates, and perception of group variability', in Stroebe, W. and Hewstone, M. (eds), European Review of Social Psychology 5: 37-68.

Marques, J. M., Yzerbyt, V. Y. and Leyens, J.-Ph. (1988), 'The black sheep effect: Extremity of judgments towards ingroup members as a function of ingroup identification', European Journal of Social Psychology 18: 1-16.

Monteiro, M. B., França, D. X. and Rodrigues, R. B. (2009), 'The development of intergroup bias in childhood: How social norms can shape children's racial behaviours', International Journal of Psychology, 44: 29-39.

Moscovici, S. (1984), 'The phenomenon of social representations', in Farr, R. and Moscovici, S. (eds), Social representations, Cambridge: Cambridge University Press.

Moscovici, S. (1972), Introduction à la psychologie sociale, Paris: Larousse.

Moscovici, S. (1961), La psychoanalyse: Son image et son public, Paris PUF.

Knoke, A. (ed.) (1982), Mudança social e psicologia social, Lisbon: Horizonte

Palma, T. A., Garrido, M. V. and Semin, G. R. (2011), 'Grounding person memory in space: Does spatial anchoring of behaviours improve recall?', European Journal of Social Psychology 41: 275-80.

Park, B., Judd, C.M. and Ryan, C. (1991), 'Social categorization and the representation of variability information', in Stroebe, W. and Hewstone, M. (eds), European Review of Social Psychology 2: 211-45.

Pereira, C., Vala, J. and Costa Lopes, R. (2010), 'From prejudice to discrimination: The justifying role of perceived threat in discrimination against immigrants', European Journal of Social Psychology 40: 1231-50.

Pinto, I. R., Marques, J. M., Levine, J. M. and Abrams, D. (2010), 'Membership status and subjective group dynamics: Who triggers the black sheep effect?', Journal of Personality and Social Psychology 99: 107-19.

Rokeach, M. (1960), The open and closed mind, New York, NY: Basic.

Silva, Sílvia C. A., Baptista, C. and Lima, L. (2004), 'OSCI: an organisational and safety climate inventory', Safety Science 42: 205-20.

Tajfel, H. and Turner, J. C. (1979), 'An integrative theory of intergroup conflict', in Austin, W. G. and Worchel, S. (eds), The social psychology of intergroup relations, Monterey, CA: Brooks/Cole, pp. 33-47. 
Turner, J. C. and Reynolds, K. J. (2001), 'The social identity perspective in intergroup relations: Theories, themes and controversies', in Brown, $\mathrm{R}$. and Gaertner, S. (eds), Handbook of social psychology, vol. 4: Intergroup processes, Blackwell: Oxford and Cambridge, MA, pp.133-52.

Turner, J. C., Hogg, M. A., Oakes, P. J., Reicher, S. D. and Wetherell, M. S. (1987), Rediscovering the social group: A self-categorization theory, Oxford: Basil Blackwell.

Vala, J. (1992), 'A investigação em psicologia', in Gago, J. M. (ed.), O estado das ciências em Portugal, Lisbon: Dom Quixote.

Vala, J. and Castro, P. (forthcoming), 'Pensamento social e representações sociais', in Vala, J. and Monteiro, M. (eds), Psicologia Social, 8th ed., Lisbon: Fundação Calouste Gulbenkian.

Vala, J., Brito, R. and Lopes, D. (1999), Expressões dos racismos em Portugal, Lisbon: Imprensa de Ciências Sociais.

Waldzus, S., Mummendey, A. and Wenzel, M (2005), 'When "different" means "worse": Ingroup prototypicality in changing intergroup contexts', Journal of Experimental Social Psychology, 41: 76-83.

\section{SUGGESTED CITATION}

Vala, J. and Costa-Lopes, R. (2012), 'Dynamics and dilemmas in social psychology: Social relations, identities and cognition', Portuguese Journal of Social Science 11: 1, pp. 3-14, doi: 10.1386/pjss.11.1.3_1

\section{CONTRIBUTOR DETAILS}

Jorge Vala is a Research Professor in Social Psychology at the Institute of Social Sciences (University of Lisbon). His research focuses on socio-cognitive processes, namely in the field of social representations and ideologies, social norms and social identities. His current projects articulate these processes with the study of racism and prejudice, immigration issues, national identity, political attitudes, social justice, and validation of everyday knowledge.

Contact for correspondence: Instituto de Ciências Sociais, Avenida Professor Anibal Bettencourt, 9, 1600-189 Lisboa, Portugal.

E-mail: jorge.vala@ics.ul.pt

Rui Costa-Lopes is a postdoctoral research fellow at the Institute of Social Sciences (University of Lisbon) in collaboration with the Radboud University Nijmegen (The Netherlands). He holds a PhD in Social Psychology from ISCTE (2009). His general research interests are on intergroup relations, prejudice and discrimination and the dynamics and effects of national identity, social norms and ideologies.

Contact for correspondence: Instituto de Ciências Sociais, Avenida Professor Anibal Bettencourt, 9, 1600-189 Lisboa, Portugal.

Phone: +351 217804700

E-mail: rui.lopes@ics.ul.pt

Jorge Vala and Rui Costa-Lopes have asserted their right under the Copyright, Designs and Patents Act, 1988, to be identified as the authors of this work in the format that was submitted to Intellect Ltd. 
Copyright of Portuguese Journal of Social Science is the property of Intellect Ltd. and its content may not be copied or emailed to multiple sites or posted to a listserv without the copyright holder's express written permission. However, users may print, download, or email articles for individual use. 